Article

\title{
The Notion of Housing Need in France: From Norms to Negotiations (19th-21st Centuries)
}

\author{
Yankel Fijalkow \\ Centre for Housing Research, LAVUE-CNRS, France; yankel.fijalkow@paris-valdeseine.archi.fr
}

Submitted: 15 July 2021 | Accepted: 1 December 2021 | Published: 31 March 2022

\begin{abstract}
This article aims to show how the concept of "housing need" has circulated between the social sciences and architectural design fields in France since the second half of the 19th century up until today. France is a particularly rich example for developing this sociohistorical overview over a long span of time, through three time periods: the beginning of housing policy which, during the hygienist period and in legal devices and statistics, defined "good housing" as opposed to inadequate housing; the debate surrounding the notion of need illustrated through an examination of mass construction since the beginning of the 1950s, in particular, that of large social housing estates which developed in response to the housing crisis and the increase of slums; and the contemporary period, that raises many questions faced by architects and urban planners concerning the persistence of forms of inadequate housing and the development of individual aspirations for well-being.
\end{abstract}

\section{Keywords}

architecture; housing needs; norms; Paris; social sciences; urban history

\section{Issue}

This article is part of the issue "The Terms of Dwelling: Re-Theorizing Housing Through Architecture" edited by Yael Allweil (Technion-Israel Institute of Technology) and Gaia Caramellino (Politecnico di Milano).

(C) 2022 by the author(s); licensee Cogitatio (Lisbon, Portugal). This article is licensed under a Creative Commons Attribution 4.0 International License (CC BY).

\section{Introduction}

The notion of "housing need" is the focus of a significant amount of literature in numerous countries (Balchin, 1981). It intersects demographic growth-in particular the evolution of a number of households-with housing construction (Ytrehus, 2000), very often finding itself with inadequacies, which are expressed in terms of household type (i.e., family, single person, young people, workers, elderly), housing type (depending on size or status, such as social or public housing, private rental sector, homeownership, etc.), and location (i.e., tension zones in the property market). This type of statistic is intended to guide the strategies of governments confronted with the "housing crisis" at different levels (Heslop \& Ormerod, 2019; Kleinman, 1995; Schwartz, 2011). However, while it does make it possible to highlight inequalities, it struggles to identify latent needs that are not expressed explicitly (such as young adults as they move out of their parents' home) and that tend to diversify alongside changes in contemporary lifestyle (for example, singleparent families, reconstituted families, or couples who live apart; Baron Pollak, 1994). Furthermore, this type of statistic can also be critiqued for its narrow understanding of what is considered housing, as a diversity of forms continue to emerge in this domain-such as co-living, co-housing, tiny homes, temporary or timeshare occupancy statuses-as well as more marginal forms, whether desired or imposed, such as year-round camping or ecological yurts (which are not taken into account by statistics; O'Dell et al., 2004).

The problem of scarcity, speculation, and housing inadequacy has given rise to mass protests throughout the world: France (2007), Israel (2011), Spain (2012), Great Britain (2016), Argentina (2018), and Chile (2020). According to the United Nations, in 2020, the homeless represented 800 million people worldwide, with slum-dwellers in developed countries corresponding to 
a similar figure (862 million; UN-Habitat, 2020). This reflects the brutal inadequacy of housing (Sassen, 2014) as well as eviction mechanisms. While the right to adequate housing is stated in Article 25 of the Universal Declaration of Human Rights, statistics that measure housing issues-such as overcrowding, lack of facilities (like missing bath or toilet), a leaking roof inside the house, or insufficient natural light-showed that, in $2009,5.5 \%$ of vulnerable households were located in the EU (Turkington \& Watson, 2014). These indicators demonstrate the difficulties faced by national housing systems in responding to a demand that is not only statistical, but that also reflects the lifestyles of diverse populations.

Considerations of quantitative housing need, however, have not always been disconnected from qualitative and architectural dimensions. This article aims to show how the concept of "housing need" has circulated between the social sciences and architectural design fields in France since the second half of the 19th century up until today. The notion of circulation makes it possible to understand processes of interpretation and commonality between the different fields of thought (Fijalkow, 2018) but also to better grasp the normative narratives of experts.

France is a particularly rich example for developing this sociohistorical overview over a long span of time, i.e., through three time periods. It allows us to first identify the beginning of housing policy which, during the hygienist period, can be seen in the public interventions of Baron Haussmann (1852-1870), and in legal devices and statistics defined "good housing" as opposed to inadequate housing. Second, the debate surrounding the notion of need is illustrated through an examination of mass construction since the beginning of the 1950s, in particular that of large social housing estates which developed in response to the housing crisis and the increase of slums (Cupers, 2014). Finally, the contemporary period raises many questions faced by architects and urban planners concerning the persistence of forms of inadequate housing and the development of individual aspirations for well-being.

\section{Comfort and the Notion of Need: Theoretical Aspects}

Our approach to housing need integrates Foucault's (1977) theory on governability of the self and the power of panopticon within housing, insofar as comfort facilities establish domestic practices (i.e., sanitary facilities in the 19th century, or home automation in the 21st century). Nevertheless, we distance ourselves from an intentionalist perspective, considering comfort in housing as an interdisciplinary and professional field according to Bourdieu's theory (Cohen, 2011) that is the subject of negotiations, interpretations, and reconstructions (Barthe et al., 2014). Expressed through norms, comfort thus reveals power relations between actors (such as the state, landlords, or professional organizations) while also expressing the practices of inhabitants with memories of norms, but who depend on facilities imposed by policy direction.

Indeed, the notion of norm with respect to housing is represented at several levels. On the one hand, there are construction requirements, such as room size and sanitary facilities; on the other hand, there are social and behavioral requirements, such as hygiene rules. Norms are thus imposed both on builders, who must respect a certain quality in order to enter the market, and on residents, in order to gain access to housing and not get evicted. Moreover, if certain norms primarily aim to make housing tradeable on the market, they are also affected by the social practices that distinguish different types of housing. Indeed, the housing standardization process, which is based on the installation of basic utilities (i.e., sanitation, ventilation, lighting, heating, etc.), inevitably confronts the practices of inhabitants.

Norms and standards were therefore at the heart of state implemented housing policy when it appeared in the 19th century as part of the fight against housing inadequacy and the construction of social housing. Today, this policy works as a field structured by actors, opinions, and rules of action in which the state still plays an important, if not dominant, role. In France, "good housing" is defined by the Civil Code as well as the Housing and Urban Planning Code (in the name of public health and for the preservation of the planet). More recently, however, it has come to be defined by private actors through "certifications" which certify housing quality in terms of energy consumption. These certifications are a guarantee of quality and contribute to the value of buildings (Fijalkow, 2018). Like Bourdieu, we can thus speak of a normative field of housing which involves architects, developers, landlords, local authorities, and associations (McKee, 2011), all of which claim to have the skills to define what is "good housing." Within this framework, there are conflicts of legitimacy between actors, negotiations between those in a dominant position, and an integration of social issues when they threaten the social equilibrium. In recent years, this has even further complexified with the arrival of private actors and environmental construction norms which address both construction quality and household energy practices. Like in other European countries, France is witnessing a decentralization of norms, impacting both local authorities and private actors (Bevir et al., 2003).

The notion of comfort has simultaneously evolved on an individual scale. According to historian John E. Crowley (2001, p. 291), the notion of comfort, introduced in the 19th century in Great Britain and the United States, encompasses a technical definition: "self-conscious satisfaction with the relationship between one's body and its immediate physical environment." As demonstrated by Miller (1983), suburbanization in the United States throughout the 20th century has rendered comfort increasingly technological, 
integrating utilities (i.e., sanitary, household appliances, recreational) and systems (i.e., running water, heating, ventilation, home automation) that involve energy expenditure. Le Goff (1994) shows that, in France, the ideas of economic development and comfort are interconnected in such a way that comfort is considered a legitimate result of progress and a way of displaying social status. In France, the National Institute of Statistics and Economic Studies began classifying elements of comfort in the 1946 census, taking into account whether housing consisted of a kitchen, utilities, a lavatory, electricity, gas network connection, water network connection, and sewer connection.

Comfort can therefore be seen as a set of technical, social, and cultural mediations constructed as social norms according to the collective representation of an era. This is highlighted in the work of Shove (2003), who proposes to analyze the dynamics that lead to the search for comfort and what defines it, rather than supposedly objective factors. Her generational and cultural analysis highlights differentiated relationships to technical tools, consumption, social distinction, and well-being. Furthermore, she remains attentive to various cultures and histories of housing, demonstrating homogenizing factors.

\section{Hygienic Needs: A Bedroom Policy and the Architects}

During the 19th century, housing became a political question and coincided with the search for norm-setting mechanisms. At the time, Engels' (1845/1935) famous book and essay on the question of housing (1887) were part of the dominant line of thought in literature, politics, philosophy, and economics, and were heavily influenced by the epidemics that affected European countries. Public health thus brought together doctors, politicians, and demographers.

In France, the Law on Inadequate Housing of 1850 targeted rental apartments that were "liable to threaten the life or health of inhabitants." (according to the text of the law, first article). Municipalities wishing to apply the law (which is optional) may appoint a special commission made up of a doctor, an architect, and a member of the health and human services office. The commission is tasked with going on-site and mediating between the landlord, the town hall, and the tenant or neighbor who filed the complaint. It also has the power to enforce construction work or expropriate (Fijalkow, 2000).

Baron Haussmann, for example, used the law on unfit housing to strengthen his initiatives in workingclass neighborhoods. However, his actions mainly catalyzed the decree-law of 1852 on the streets of Paris, which was much more authoritarian. While his transformation of Paris raised the "average standing" of the city and made it attractive for the bourgeoisie, no improvements were seen in the housing conditions of the poor. Walter Benjamin (1989/2009) denounced
Haussmann's extravagant urban planning, which left many slum-dwellers in the shadow of great "advancements" (large, straight boulevards lined with trees and apartment buildings made of stone). After the Paris Commune, the Inadequate Housing Commission hardened its doctrine, thanks to engineers who managed the municipal water authority as of 1869.

The consistency of insalubrity diagnoses still raised questions, however, and a universal definition of poor housing seemed necessary in order to rationalize public action. Du Mesnil, faithful successor to Villermé, wrote numerous articles on housing conditions for the Annales d'Hygiène Publique et de Médecine Légale, the journal that piloted the hygiene movement after the cholera outbreak of 1832. After a long period of debate, the City of Paris created a permanent office to organize its statistics in 1881, appointing Jacques Bertillon, doctor and demographer, as director.

In 1896, Bertillon published the first housing conditions census and mapped the overcrowding of housing. He claimed to be measuring "poor housing" although he was primarily quantifying "household congestion." Nevertheless, for the first time, a statistical evaluation of housing was conducted. Bertillon measured overcrowding in terms of "people per room." "Rooms" were considered spaces in which a bed could be placed, with a minimum dimension of 2 by 1.5 meters. Census surveyors asked households to indicate the number of "rooms" with a fireplace, as well as if the apartment contained a toilet. The results revealed that $23 \%$ of households lived in overcrowded housing, and the overcrowding map clearly outlined the working-class neighborhoods in the north-east of Paris (Figure 1). For "moral statistics," overcrowding thus reflected demographic behavior (Fijalkow, 2000). After the Paris Commune of 1871, the "moral order" dominant in politics, religion, and society sought to implement a plan to reduce overcrowding and to increase the birth rate through the construction of social housing in each arrondissement of Paris (Hanson, 2010).

How does this translate in terms of architecture? To understand the "needs" expressed by the statistics of Jacques Bertillon, it is necessary to explain what qualifies as "good housing" in the post-Haussmannian context. This period lauded an apartment inspired by the aristocratic hotel. In Haussmannian apartments, we generally find a beautiful entryway with a hallway granting access to each room. Facing the street are three adjoining reception rooms, made up of a living room, a dining room, and a bedroom. These rooms received fine architectural attention and were adorned with fireplaces, marquetry floors, and moldings. At the time, the courtyard side of the apartment was reserved for the kitchen and the servants. The partitioning of reception rooms, private rooms, as well as bedrooms and their sanitary facilities is a basic principle found in Haussmannian apartments (Eleb, 2021).

Thus, when Bertillon deplored that "in too many Parisian dwellings, working-class families live together, 


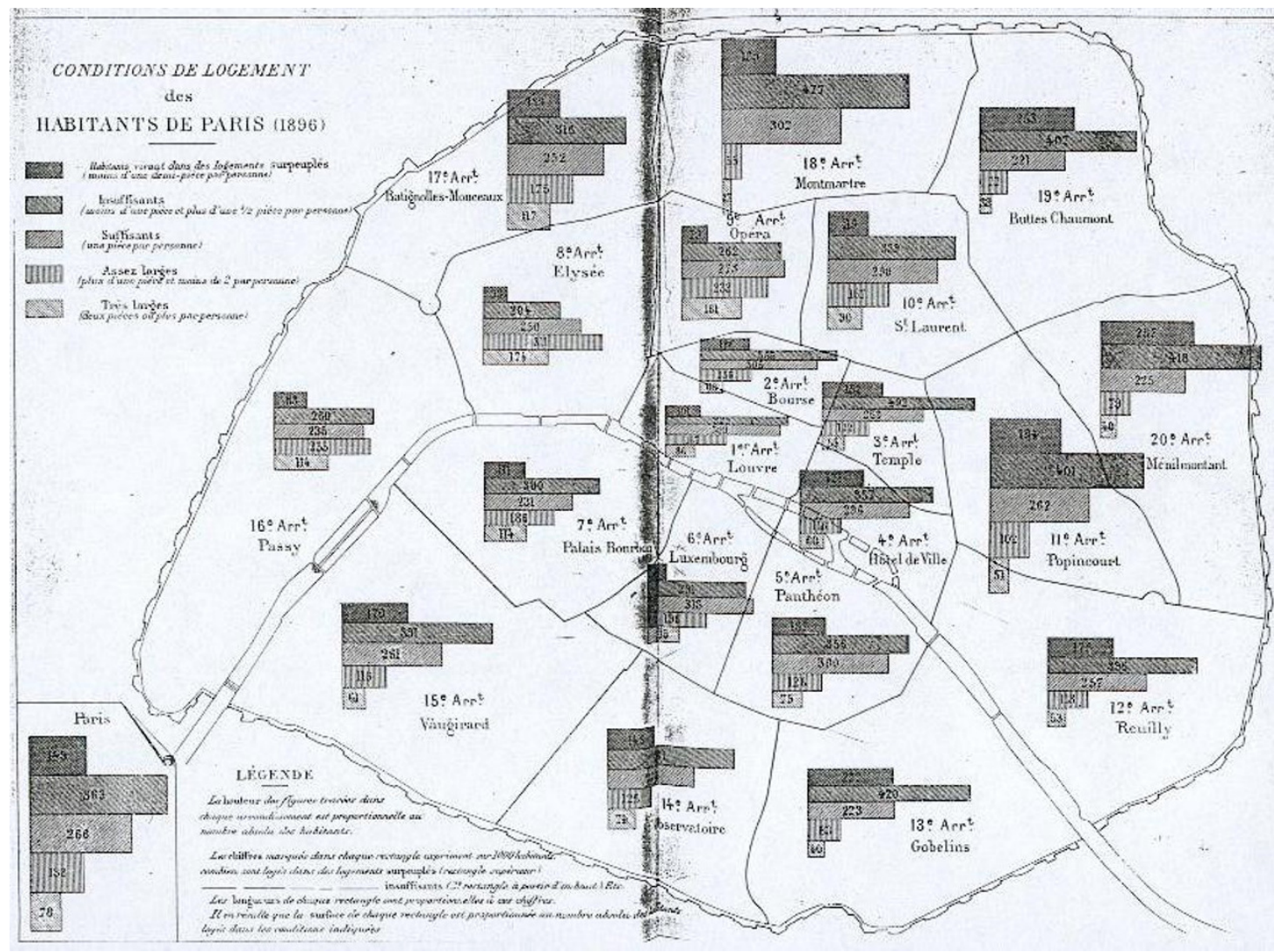

Figure 1. Housing conditions. Source: Bertillon (1894).

parents and children alike, in the same room" (Bertillon, 1894, p. 9), he referred to the architectural principles of Haussmannian housing divided by "room," "heated," intended for the "conventional, large family," and designed by architects trained at the Fine Arts School (École des Beaux-Arts). This design was opposed to the working-class way of living together in the same room in buildings built by owners.

In the second half of the 19th century, the first social housing projects were inspired by Haussmannian principles. In 1849, architect Veugny's program for the Cité Napoléon included separate rooms and water access on each floor. The housing estate was comprised of collective facilities, like a wash house, a bath house, and a children's shelter, while also preserving the autonomy and privacy of families (Bruant, 2011).

Architects were invited to participate in competitions planned by social housing organizations. Some of them, who had read Bertillon's works, gave a broader understanding of the notion of "hygienic architecture," citing Alberti's writings (Daly, 1878). Emile Trélat (1821-1907) introduced a "hygiene course" at the École Centrale d'Architecture, within which he explained the concepts of physiology and environment. Hygiene, however, remained less present at the Beaux-Arts de Paris. Louis Bonnier (1856-1946) appeared as an exception, building low-cost housing (habitat bon marché) in the Seine region, and contributing to reports on the "tuberculous blocks of Paris" alongside Paul Juillerat. He sug- gested that social housing architecture consisted of "sincerely adapting to successive needs" (Bonnier, 1920, p. 30). Augustin Rey (1864-1934), however, built the first habitat bon marché for the Rothschild Foundation, giving way to ideas on ventilation and natural lighting (Rey, 1927) which were later applied in Le Corbusier's Radiant City, in 1935.

\section{The Normative Notion of "Needs" During the Post-War Reconstruction and Social Housing Projects}

After World War II, the post-war reconstruction revealed a housing shortage, due to both collateral damage and construction delays that began at the start of the century. The housing crisis could be seen in the shortage of available housing, along with their poor and deteriorating conditions. This gave way to intense public debate, as well as social movements calling for government intervention (Castells et al., 1978).

In 1946, Duon and Lenain published a survey study on housing conditions in Paris for the National Institute of Statistics and Economic Studies, in which they found that a third of housing units had outdoor toilets and only $20 \%$ had running water. "Need" thus translated in terms of utilities, especially those related to heating and hygiene. The Ministry of Reconstruction also asked private teams to study certain areas of degraded housing by focusing on household behavior. Thus, the Economy and Humanism Team inspected each apartment in order 
to identify the housing characteristics. Heads of households were asked to answer a survey which aimed to measure the "sociability" of the inhabitants (whether they had a regular job, how the household was managed, furniture quality, lifestyle) and the "adequacy" of housing (i.e., ventilation, natural light, water supply). This made it possible to distinguish between types of families (i.e., "normal," "re-educable," etc.) as well as types of housing (i.e., inadequate, overcrowded, unhygienic, etc.; Auzelle, 1949).

With this type of survey, understandings of the notion of "need" go beyond that of technical equipment, taking into account the education of families by categorizing those who should be supported and referred to transitional housing. This type of reasoning was in line with pre-war socialist thinking on the question of "normal housing." In 1943, Henri Sellier (1883-1943), one of the pioneers of social housing, was reflecting upon post-war housing and stated in an article entitled "The Definition of Normal Housing" that its technical factors must take into account human habit (Sellier, 1943). "Need" as a concept thus required "adaptable" housing, a reflection which ushered the contribution of the social sciences. In 1953, the government finally adopted strong measures to finance and organize construction, and a process of social housing stock hierarchization was therefore put in place.

In social housing-known as HLM (habitation à loyer modéré) since 1950-distinctions developed between populations corresponding to different needs. Construction norms thus allowed for the HLM to be hierarchized by social standing. A distinction was created between HLM " $A$ " and HLM " $B$," which was based on whether the kitchen was designed to be used for meals. If so, it was considered HLM " $A$ " and the size of the kitchen increased in detriment of the living room; if not, it was considered HLM " $\mathrm{B}$ " and the living room was prioritized. Housing managers justified this distinction with a more "rural" and "working class" version, and it was adopted by many architects of the post-war reconstruction period (Dubuisson, Prouvé, Lods). In 1957, architect Jean Prouvé (1901-1984) developed a project along the same lines, but which was aimed at the poorest populations. It consisted of a minimalist, less expensive housing development that was well equipped with heating and hygiene facilities. Here, we can observe the appearance of social hierarchy processes and a search for standardization.

To this end, a convergence of views between demographers and modern architects, who were attentive to the functioning of rooms and occupancy norms, can be seen. In 1946, the scientific journal Population, published by the French Institute for Demographic Studies, examined this pertinent issue. Demographer Alfred Sauvy promoted housing policy as a vehicle for birth rate policy, asserting that "the aging of our heritage, a consequence of human aging, is an important and essential cause for our current impoverishment" (Sauvy, 1946, p. 441). In the same publication, the renowned architect Le Corbusier proposed a functionalist action program based on his "modulor" model, in which he expressed:

What is the key element of the apartment? The bedroom. We are all familiar with this room: squareshaped with a bed at its center, a lightbulb hanging from the ceiling...it's the quintessence of inhospitable. Each member of the family, children and parents alike, must be able to have their own private haven, where they can be "left alone," where they can have their own workspace, where there is enough room for physical activity. (Le Corbusier, 1948, p. 420)

Le Corbusier's understanding of "needs" led to a normative understanding of housing practices. This convergence, around the notion of "need," and in favor of a normalized and hierarchized architecture based on lifestyle, was accepted by sociologist Chombart de Lauwe. In his research, the concept of overcrowding remained central in the evaluation of needs. As the first French urban sociologist in the post-war period, Chombart de Lauwe established an index based on the number of people per room as well as the surface area. This index allows us to:

Determine thresholds below which physical diseases and behavioral disorders are likely to appear...below a certain surface area, family life becomes more and more difficult to bear. The woman, harassed by her children and exhausted by laundry, quickly burns out in a house that she cannot even arrange to her liking or keep clean. (Chombart de Lauwe, 1956, p. 80)

According to the author, this threshold is situated between eight and 14 square meters per person. It also supported the journalistic narrative on Sarcellitis, an illness found in large housing estates that especially impacted the psychology of women and children (see Sarcelles, Figure 2). It corresponded to the position of sociologists who, like the hygienists of the 19th century, wanted to have a say in architectural projects, which turned out to be a failure with regard to the economic conditions of large housing estate production.

Hygiene and well-being were concepts that guided his approach to housing needs. This minimalist and functionalist vision of responding to needs was widely shared at the time. It fell in line with the considerations of Doctor Goromosov (1968) of the World Health Organization on physiological needs and the microclimate of housing.

At the end of the 1960s, however, a sociological alternative emerged when Henri Lefebvre (1968) revealed the working class need for a "right to the city" and an appropriation of space, in the face of "de-urbanizing urbanization." Criticism of large housing estates thus took on another dimension, simultaneously combining social, symbolic, and architectural factors. In response, Chombart de Lauwe tried to distinguish between "needs" and "aspirations," referencing the work of Maslow (1954) 


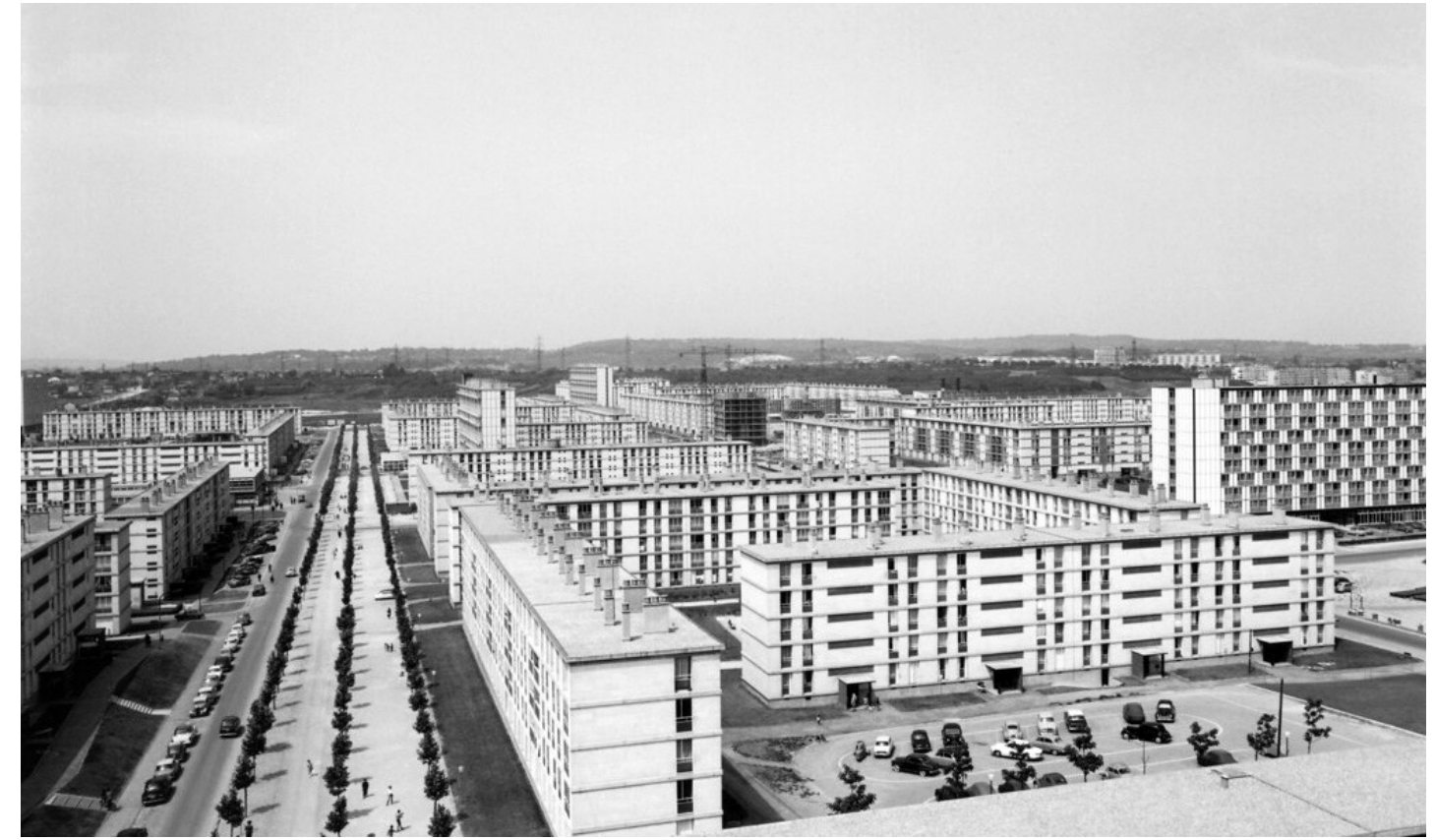

Figure 2. Sarcelles, an emblematic case. Source: INA (2018).

who placed self-esteem at the very top of the pyramid of needs. Indeed, if "needs" refer to physiological factors, "aspirations" express the attachment of a social group to their space. This also conforms to the principles of social morphology analysis established by Maurice Halbwachs and Marcel Mauss, founders of housing sociology. Halbwachs considered that "the material forms of society act upon it, not by virtue of a physical constraint, as a body would act, on another body, but by consciousness that we take of it" (Halbwachs, 1938, pp. 182-183).

Based on this theoretical view, Chombart de Lauwe agreed with the point of view of public authorities regarding the "needs" of populations in terms of technical equipment, while also considering lifestyles and the emerging trend that questioned the appropriation of urban spaces, revealing himself to be quite critical towards modern urban planners and architects.

\section{Current Period (Since 1990): The Search for Essential Features and "Quality" in Architecture}

Since the 1990s, the notion of need has covered several dimensions, linking social science research and public action. The first is poor housing and residential vulnerability, which reappeared in 1995 . According to the Abbé Pierre Foundation (2021), which relies on official data from the National Institute of Statistics and Economic Studies, there are nearly four million people in France living with housing difficulties. This includes the homeless, those living in camps, households in situations of overcrowding, and those with energy insecurity. There also exists fewer extreme situations of "residential vulnerability," which stem from property value, lack of residential flow, social tension between landlords and tenants, and distance to work location. The conclusion shared by political institutions, housing actors, and civic action spheres is a quantitative increase in housing construction. This, however, only allows for the needs of new households arriving each year on the housing market to be met. The existing housing stock, a third of which was built before World War II and which houses young, immigrant, and disadvantaged households (Lévy \& Fijalkow, 2010), would also need to be renovated, which would involve significant financial efforts from public institutions. Public policy tools to fight against inadequate housing buildings are being developed, although they remain insufficient. Tenants can also report indecent housing conditions to a judge. However, some landlord unions, and even those who build public housing for home ownership, are in support of a minimalist trend in terms of housing norms. To make the market more flexible and to reduce their costs, they oppose construction norms that are too numerous and that pose too many constraints (Fijalkow, 2015). Although inordinate, their positions lead to a reflection on the essential features of housing. For this reason, recent decrees requiring builders to adapt housing to be handicap accessible were made more flexible.

The second type of need involves considering the desires of inhabitants through participatory devices that give voice to users. This method, in accordance with Lefebvre's proposals, more often concerns the surrounding environment than the interior of housing, except in certain cases of collective production. It is more often applied in social housing districts targeted by public policies (Cupers, 2011). In the context of pauperization, the consideration of needs includes the demand for security and public spaces, but also the difficulties resulting from 
divisive processes and a lack of residential opportunities, in particular for young working people and marginalized populations, and, recently, little towns. Criticism of housing standards, however, also leads to the increasingly widespread practice of collaborative architecture in housing associations. This can lead to the collectivization of services that were previously integrated into housing.

The third type of need relates to sustainable housing and the control of energy expenditure. In this context, a recent decree has led us to consider heating difficulties in certain poorly insulated apartments as a characteristic of inadequacy and poor housing that affects underprivileged populations. Among other demands, the Gilets Jaunes movement that erupted in the fall of 2019 also underlined the difficulties of the low middle class living far from their place of work and their considerable energy expenditure for travel. For them, the concept of "need," or "aspiration," expresses a need for integration and environmental control.

Faced with these forms of housing needs, the architectural responses turned out to be negotiated responses (Eleb \& Simon, 2014) depending on the recipient: public housing, social housing, private housing, or low-cost home ownership. They could address housing surface area, in order to counter its declining trend over the last 20 years, according to a recent report by Lemas (2020). The idea of "an additional space," necessary for storing belongings, extending functional rooms, or receiving guests, is intended to be a response to various needs. This concern is linked to the need for more storage space, unlike changes dictated by the optimization of resource use. This issue coincided with the demand for greater flexibility in housing depending on the family structure: conventional, single-parent, stepparent, or the presence of young adults and the elderly.

A good architectural example is the renovation of the Bois-le-Prêtre Tower in Paris, which extended each apartment to include a "winter garden." The search for additional space was fundamental to the rehabilitation of this building built in the early 1960s. It consisted of adding a three-meter-wide extension to the apartments through a self-supporting structure surrounding the perimeter of the tower, comprised of a two-meterwide winter garden and a one-meter balcony. In addition, this project opened a dialogue with the inhabitants, who constituted the competition jury in 2005. Residents were first presented a show apartment, which was followed by a resident vote, resulting in favor of the rehabilitation project. The architects Fréderic Drout, Anne Lacaton, and Jean-Philippe Vassal then began implementing the renovation. Tenants were able to participate in the process through workshops.

The quality of outdoor public space and services is also illustrative of the architectural objectives which set out to meet the needs mentioned above. In this regard, the Parisian project known as Diapason is also exemplary. Vegetation is omnipresent in the community garden on the ground floor, in shared green terraces, on private balconies with plants, and in vegetable gardens. Energy performance even exceeds regulatory requirements. The set-up of the operation consisted of a particular construction method: Individual private buyers came together in a cooperative (Diapason group) to create their own housing project, as part of a development initiative for the City of Paris. The project mainly focused on the sharing of spaces and facilities: 14 apartments share a vegetable garden, common storage areas, a laundry room, a shared studio for guests, a bicycle storage room, and a workshop. This architectural interpretation reveals that the notion of comfort, and therefore of need, falls within a dimension that is both emotional and moral in terms of household. Not only were everyone's desires taken into account, but it was also important that the place of residence be the outcome of a chosen community's expression, and that it carries the ethical values of solidarity and ecology.

This discourse responds well to the reflections of certain essayists, architects, and sociologists on the essential qualities of housing seen from the point of view of the individual. For Chollet (2016), the search for "home" is a fundamental value that opposes mechanisms of the phenomenon of living space reduction that she refers to as the "great eviction." Gallagher (2007) provides an American example of this theory in his book House Thinking, which aims to show how the arrangement of each room in the American home reflects the person who lives in it, and also conditions their behavior. Sartoretti (2013), in turn, raises the question of industrial apartment furniture production, which homogenizes and universalizes living conditions. These reflections show that housing is at the center of conflicting values, divided between the needs of individuals, ecology, and material comfort. In terms of heating materials, for example, the range of values, which are increasingly sensitive to eco-citizenship, puts in tension the aspiration for "civic frugality" (and, therefore, ecologic) and the hedonism of comfort that enlarge the sense of the "needs." In a recent survey, we showed that, while many homeowners do not seem ready to adapt their heating and while others seek to regulate their habits with the help of technology, all of them allude to the search for well-being and comfort (Fijalkow \& Maresca, 2018).

\section{Conclusions}

The history of the notion of "need" allows us to identify the narratives and values on which housing policies and their architecture are based. This historical overview attests to the succession of norms carried out by different actors with different objectives, as well as the processes of interpretation from one professional field to another. During the hygienic period, the concept of overcrowding dominated the debate on the definition of good housing and allowed architects to emphasize the importance of rooms. During the modern period, the notion 
of need enabled the emergence of technical standards and the hierarchy of forms of housing that were justified by the search for adaptation. Today, contrary to the discourse put forth by Heidegger in 1951, the ethics of inhabiting does not reside in its isolation, as philosophers once thought, but in its capacity for individuality and hospitality, as contemporary experiments have shown (Sennett, 2018). In this respect, social housing organizations, which played a central role as a meeting place between social sciences and architecture in the first two periods, are less present today. This has the effect of being more attentive to the inhabitants, of developing new procedures for negotiating standards between the actors, but of dispersing the reflection on the quality of housing.

Our exploration of the question of "need" shows that three trends are exercised today in the field of housing: standardization, hierarchization, and the search for alternatives. In a context of hybridization of forms of housing production, both private and state-led, and of lifestyle and demographic reconstruction, we are witnessing a dynamic of archipelization; that is, a diversification of needs. This results in the multiplication of systems of norms, values, and sub-markets. In this sense, France offers a particular trajectory of the evolution of the notion of "need," illustrated by a strong assumption of responsibility for housing by the public authorities in the 20th century. The progressive privatization requires comparisons with other countries, particularly after the Covid-19 pandemic, which forced the State to intervene in social and economic life and to rethink the notion of housing quality.

\section{Acknowledgments}

I would like to thank Danya Kiernan (translation) and my colleagues and PhD students for their remarks. This publication is based upon work from COST Action, European Middle Class Mass Housing (MCMH-EU) CA 18137 supported by COST (European Cooperation in Science and Technology). www.cost.eu

\section{Conflict of Interests}

The author declares no conflict of interests.

\section{References}

Abbé Pierre Foundation. (2021). On bad housing conditions in France.

Auzelle, R. (1949). Recherche d'une méthode d'enquête sur l'habitat défectueux [Researching a method for investigating inadequate housing]. Vincent, Fréal et Cie.

Balchin, P. (1981). Housing policy and housing needs. Palgrave Macmillan.

Baron Pollak, P. (1994). Rethinking zoning to accommodate the elderly in single family housing. Journal of the American Planning Association, 60(4), 521-531. https://doi.org/10.1080/01944369408975608

Barthe, Y., Callon, M., \& Lascoumes, P. (2014). Agir dans un monde incertain. Essai sur la démocratie technique [Acting in an uncertain world. Essay on technical democracy]. Média Diffusion.

Benjamin, W. (2009). Paris, capitale du XIXe siècle: Le livre des passages [Paris, capital of the 19th century: The book of passages]. Les Éditions du CERF. (Original work published 1989)

Bertillon, J. (1894). Essai de statistique comparée du surpeuplement des habitations à Paris et dans les grandes capitales européennes [Essay on the comparative statistics of overcrowding in Paris and in the major European capitals]. Imprimerie Chaix.

Bevir, M., Rhodes, R. A., \& Weller, P. (2003). Traditions of governance: Interpreting the changing role of the public sector. Public Administration, 81(1), 1-17.

Bonnier, L. (1920). L'esthétique et l'architecture dans le concours pour le Plan d'aménagement et d'extension de Paris [Aesthetics and architecture in the competition for the Paris Development and Extension Plan]. La Vie Urbaine, 1920(5), 30-31.

Bruant, C. (2011). La Cité Napoléon: Une expérience controversée de logements ouvriers à Paris [The Napoleon housing estate, a controversial experiment in workers' housing in Paris]. LéaV.

Castells, M., Cherki, E., Godard, F., \& Mehl, D. (1978). Crise du logement et mouvements sociaux urbains: Enquête sur la région parisienne [Housing crisis and urban social movements: A survey of the Paris region] (Vol. 14). Mouton.

Chollet, M. (2016). Chez soi [At home]. La Découverte.

Chombart de Lauwe, P. (1956). La vie quotidienne des familles ouvrières [The daily life of worker families]. CNRS Éditions.

Cohen, A. (2011). Bourdieu hits Brussels: The genesis and structure of the European field of power. International Political Sociology, 5(3), 335-339.

Crowley, J. E. (2001). The invention of comfort: Sensibilities \& design in Early Modern Britain \& Early America. Johns Hopkins University Press.

Cupers, K. (2011). The expertise of participation: Mass housing and urban planning in post-war France. Planning Perspectives, 26(1), 29-53.

Cupers, K. (2014). The social project: Housing postwar France. University of Minnesota Press.

Daly, C. (1878). De l'hygiène publique et privée [On public and private hygiene]. Revue de l'Architecture et des Travaux Publics, V(13/14).

Duon, G., \& Lenain, P. (1946). Documents sur le problème du logement à Paris [Documents on the housing problem in Paris]. Imprimerie Nationale.

Eleb, M. (2021). Naissance et évolution des espaces de l'intime en France [Birth and evolution of intimate spaces in France]. Dix-Neuf, 25(2), 99-110. https:// doi.org/10.1080/14787318.2021.1926873

Eleb, M., \& Simon, P. (2014). Le logement contemporain: Entre confort, désir et normes (1995-2012) [Contem- 
porary housing: Between comfort, desire and standards (1995-2012)]. Primento.

Engels, F. (1887). The condition of the working class in England. John W. Lovell.

Engels, F. (1935). The housing question. International Publishers. (Original work published 1845)

Fijalkow, Y. (2000). La notion d'insalubrité. Un processus de rationalisation 1850-1902 [The notion of unhealthyness. A process of rationalization 1850-1902]. Revue d'Histoire du XIXe Siècle, 2000(20/21), 135-156. https://doi.org/10.4000/ rh19.213

Fijalkow, Y. (2015, June 3). De la rénovation urbaine au développement durable: Du poids des normes dans le logement (XIXe-XXle siècles) [From urban renewal to sustainable development: The weight of standards in housing (19th-20th centuries)]. Métropolitiques. https://metropolitiques.eu/De-larenovation-urbaine-au.html

Fijalkow, Y. (2018). Governing comfort in France: From hygienism to sustainable housing XXth-XXIst century. Housing Studies, 34(6), 1021-1036. https://doi.org/ 10.1080/02673037.2018.1509947

Fijalkow, Y., \& Maresca, B. (2019). Normes de chauffe et transition énergétique: Les transactions des habitants [Heating standards and energy transition: Residents' transactions]. Natures Sciences Sociétés, 27(4), 410-421.

Foucault, M. (1977). Discipline and punish: The birth of the prison. Allen Lane.

Gallagher, W. (2007). House thinking: A room-by-room look at how we live. Harper Perennial.

Goromosov, M. S. (1968). Bases physiologiques des normes d'hygiène applicables au logement [Physiological basis of hygiene standards for housing]. Organisation Mondiale de la Santé. http:// apps.who.int/iris/bitstream/handle/10665/41498/ WHO_PHP_33_fre.pdf?sequence=1\&isAllowed $=y$

Halbwachs, M. (1938). Morphologie sociale [Social morphology]. Armand Colin.

Hanson, S. E. (2010). The founding of the French Third Republic. Comparative Political Studies, 43(8/9), 1023-1058. https://doi.org/10.1177/001041401037 0435

Heslop, J., \& Ormerod, E. (2019). The politics of crisis: Deconstructing the dominant narratives of the housing crisis. Antipode, 52(1), 145-163. https://doi.org/ 10.1111/anti.12585

INA. (2018, May 25). 1960: Le nouveau Sarcelles [1960: The new Sarcelles] [Video]. https://www.youtube. com/watch?v=0osldxBGDqY

Kleinman, M. (1995). Meeting housing needs through the market: An assessment of housing policies and the supply/demand balance in France and Great Britain. Housing Studies, 10(1), 17-38. https://doi. org/10.1080/02673039508720807

Le Corbusier. (1948). L'habitation moderne [The modern house]. Population, 3(3), 417-440.

Le Goff, O. (1994). L'invention du confort, naissance d'une forme sociale [The invention of comfort, birth of a social form]. Presses Universitaires de Lyon.

Lefebvre, H. (1968). Le droit à la ville [The right to the city]. Anthropos.

Lemas, P.-R. (2020). Rapport au Ministre du logement sur la qualité des logements sociaux [Report to the Ministry of Housing on the quality of social housing].

Lévy, J.-P., \& Fijalkow, Y. (2010). Les politiques du logement [Housing policies]. In O. Borraz \& V. Guiraudon (Eds.), Politiques publiques 2: Changer la société [Public policies 2: Changing society] (pp. 113-138). Presses de Sciences Po.

Maslow, A. H. (1954). Motivation and personality. Longman.

McKee, K. (2011). Sceptical, disorderly and paradoxical subjects: Problematizing the "will to empower" in social housing governance. Housing, Theory and Society, 28(1), 1-18. https://doi.org/10.1080/ 14036091003788120

Miller, R. (1983). The hoover in the garden: Middle-class women and suburbanization, 1850-1920. Environment and Planning D: Society and Space, 1(1), 73-87.

O'Dell, W., Smith, M. T., \& White, D. (2004). Weaknesses in current measures of housing needs. Housing and Society, 31(1), 29-40. https://doi.org/ 10.1080/08882746.2004.11430496

Rey, A. (1927). Hygiène de I'habitation [Hygienic housing]. In L. Martin \& G. Brouardel (Eds.), Traité d'hygiène [Hygiene treaty] (Vol. 16, pp. 250-252). Librairie Baillère.

Sartoretti, I. (2013). Intimi universi [Intimate universes]. Mimesis.

Sassen, S. (2014). Expulsions: Brutality and complexity in the global economy. Harvard University Press.

Sauvy, A. (1946). Logement et population [Housing and population]. Population, 1(3), 441-452.

Schwartz, A. (2011). Lessons from the housing crisis. Family and Consumer Sciences Research Journal, 40(1), 3-14. https://doi.org/10.1111/j.15523934.2011.02084.x

Sellier, H. (1943). Définition du logement normal [Definition of normal housing]. Musée Social, 1, 4-15.

Sennett, R. (2018). Building and dwelling: Ethics for the city. Allen Lane.

Shove, E. (2003). Comfort, cleanliness, convenience: The social organization of normality. Berg Publishers.

Turkington, R., \& Watson, C. (Eds.). (2014). Renewing Europe's housing. Policy Press.

UN-Habitat. (2020). World cities report 2020: The value of sustainable urbanization.

Ytrehus, S. (2000). Interpretation of housing needs? A critical discussion. Housing, Theory and Society, 17(4), 166-174. https://doi.org/10.1080/1403609 00300108591 


\section{COGITATIO}

\section{About the Author}

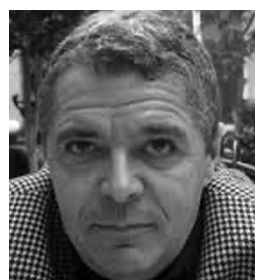

Yankel Fijalkow is a professor of social sciences and urban planning and is co-director of the Centre de Recherche sur l'Habitat (LAVUE CNRS). He is also the author of several books: Sociologie des Villes (Sociology of Cities; 2011), Sociologie du Logement (Sociology of Housing; 2016), Dire la Ville c'est Faire la Ville (To Say the City is to Make the City; 2017), Récits de la Ville Malade (Narratives on the Sick City; 2021). 